\section{Antibiotics: avert an impending crisis}

Bacterial pathogens are rapidly becoming resistant to almost all antibiotics (Nature 495, 141; 2013). To make matters worse, the drug-discovery pipeline of new antimicrobials is almost empty (M. S. Butler and M. A. Cooper Curr. Drug Targets 13, 373-387; 2012). The major funding bodies therefore need to give top priority to research into antibiotic discovery and resistance.

In a snapshot survey last month of the websites of 11 of the world's largest medical and scientific research-funding agencies (in the United States, Europe, Canada and Australia), I found none that allocated substantial grant money to antibiotic discovery or development, or to research on antibiotic resistance.

The funding agencies I have surveyed might argue that properly constructed applications all receive a fair hearing, but that is not the same thing. Researchers are generally adept at tailoring their grant proposals to fit funding priorities, particularly when prompted by a large financial carrot.

Peter Speck Flinders University, Adelaide, Australia. peter.speck@flinders.edu.au

\section{Antibiotics: relax UK import rule on fungi}

With the UK Chief Medical Officer last month highlighting the "catastrophic threat" of antibiotic-resistant bacteria (see Nature 495, 141; 2013), we suggest that the United Kingdom re-evaluates its misplaced overregulation of importing fungi for research. This is obstructing a potentially effective route towards alleviating the antibiotics crisis.

Some of the most successful antimicrobials, among other pharmaceuticals, are derived from fungi - including penicillins, cephalosporins, cyclosporins, griseofulvins and pneumocandin. Given that only
$2-12 \%$ of all estimated fungal species have been described and less than half of those in the GenBank database have been named, unknown fungi may have the greatest potential for yielding new pharmaceuticals.

As implemented, The Plant Health (England) Order of 2005 requires an import licence for all live fungi. Licensing requires the species to be named and riskassessed, preventing researchers from using any unknown fungi.

The biggest risk to plant and human health is from fungal spores entering the country accidentally: for example, in dust and soil on vehicles, shoes, packaging, migrating birds or insects, and horticultural products. Considering the scale of this unregulated import of spores, we suggest that the constraints imposed by current policies are unrealistic as well as counterproductive.

David L. Hawksworth

Universidad Complutense de Madrid, Spain; and The Natural History Museum, London, UK. d.hawksworth@nhm.ac.uk Bryn T. M. Dentinger Aberystwyth University, Aberystwyth, UK.

\section{Naples fire inflames rise in creationism}

On the night of 4 March, unknown arsonists destroyed the famous City of Science centre in Naples. This shocking event has been publicly welcomed by some hardline creationists in Italy, who disapprove of the teaching of evolution at the centre.

However, the minister for education and research, along with the mayor and the regional governor, have agreed to reconstruct the buildings within two years. The founder of the City of Science, physicist Vittorio Silvestrini, announced that the centre will open new exhibition areas in the surviving buildings and gardens this week - backed by donors and other science museums. In the week after the fire, about 10,000 people from Naples marched in protest against the arson attack.

The conservative commentators who instead seemed to rejoice at the centre's destruction include the national newspaper Il Foglio, which applauded the flames as purification against the scourge of evolutionism - "a nineteenth-century superstition" destined to bring young people to "despair and simian behaviours". This inflammatory anti-Darwinism has been rapidly amplified on the Internet.

Italy's current climate of political uncertainty seems to have fostered an unexpected resurgence in creationism with science education a prime target.

Telmo Pievani University of

Padua, Italy.

dietelmo.pievani@unipd.it

\section{Guaranteeing high standards takes time}

My impressions from a 17-year tenure at the US National Research Council (NRC), part of the National Academy of Sciences, do not tally with Marjory Blumenthal's views of the academy's performance (Nature 494, 423-424; 2013).

The NRC's investment in procedures aimed at assuring objectivity, independence and scientific rigour is impeccable. Ensuring the credibility of scientific advice takes time. The process cannot be influenced by the impatience of advocates under pressure from their clients, despite today's expectations for rapid information. It would indeed be desirable for the NRC to be more "nimble", but not at the expense of its scientific standards.

I find it commendable that the NRC holds steady in its allegiance to fulfil its advisory role. In brushing over the complexities of process and product, I believe that Blumenthal misjudges the pursuit of consensus as a worthy end in itself. Michael Feuer The George Washington University, Washington DC, USA. mjfeuer@email.gwu.edu

\section{Anonymity of sperm donors under threat}

Personal genomics services are becoming popular for genealogical or ancestry-tracing purposes (see, for example, go.nature.com/scbwci). But this direct-to-consumer practice undermines promises of spermdonor anonymity, which is still common in clinics in many countries (see also M. Angrist Nature 494, 7; 2013).

Adults conceived from donor sperm can now identify their biological fathers using DNA testing (see R. Lehmann-Haupt Slate, 1 March 2010). In doing so, they could be unwittingly infringing the gamete donor's constitutional right to privacy.

Companies selling personal genetic testing therefore have a responsibility to inform customers about the potential risk of privacy breaches, as do clinics accepting gamete donors. Pascal Borry, Olivia Rusu KU Leuven, Belgium. pascal.borry@med.kuleuven.be Heidi C. Howard INSERM and University of Toulouse III - Paul Sabatier, France.

\section{Two sentences to impress}

Roberta Kwok might have sold her message 'Two minutes to impress' more effectively if she had followed her own example and presented her points as a quick-fire "elevator speech" (Nature 494, 137-138; 2013). Josef Settele Helmholtz-Centre for Environmental Research UFZ, Halle, Germany. josef.settele@ufz.de 